\title{
PENGGUNAAN ALAT PERAGA MISTAR BILANGAN BULAT UNTUK MENINGKATKAN HASIL BELAJAR SISWA KELAS VI SDN 8 LABUAN PADA MATERI PENJUMLAHAN DAN PENGURANGAN BILANGAN BULAT
}

\author{
Lisman $^{1}$, Wahyuni H. Mailili \\ ${ }^{1}$ SDN 8 Labuan \\ lisman@gmail.com \\ ${ }^{2}$ Program Studi Pendidikan Matematika, FKIP, Universitas Alkhairaat \\ Nuning06match@gmail.com
}

\begin{abstract}
ABSTRAK
Tujuan penelitian ini adalah mendeskripsikan penggunaan alat peraga mistar bilangan bulat dalam meningkatkan hasil belajar siswa kelas VI SDN 8 Labuan pada materi penjumlahan dan pengurangan bilangan bulat. Jenis penelitian ini mengacu pada penelitian tindakan kelas (PTK) dengan pendekatan kualitatif. Rancangan penelitian ini menggunakan model Kemmis dan Mc.Taggart yang terdiri dari: 1) perencanaan 2) pelaksanaan tindakan 3) observasi dan 4) refleksi. Teknik pengumpulan data yang digunakan adalah pemberian tes, wawancara, observasi dan catatan lapangan. Instrument yang digunakan berupa tes berbentuk uraian. Pengumpulan data dilakukan melalui tiga tahap yaitu: (1) mereduksi data, (2) menyajian data, dan (3) menarik kesimpulan. Hasil penelitian menunjukkan, pada aktivitas siswa dan aktivitas guru dalam kegiatan pembelajaran pada siklus I mencapai kategori Baik dan siklus II sangat baik, Hasil analisis tes akhir siklus I diperoleh hasil persentase nilai rata-rata dengan daya serap siswa mencapai $74,11 \%$ dan ketuntasan belajar secara klasikal mencapai persentase 77,78\% dari 18 siswa. Sedangkan pada analisis tes akhir siklus II mengalami peningkatan sesuai hasil observasi kegiatan siswa dan guru, persentase nilai rata-rata daya serap siswa mencapai $80,22 \%$ dengan ketuntasan belajar secara klasikal mencapai target persentase $100 \%$ dari 18 siswa. Hal ini telah menunjukkan ada peningkatkan hasil belajar siswa kelas VI SDN 8 Labuan pada materi penjumlahan dan pengurangan bilangan bulat dengan penggunaan alat peraga mistar bilangan bulat.
\end{abstract}

Kata Kunci : Alat Peraga mistar bilangan bulat, Hasil Belajar matematika, penjumlahan dan pengurangan bilangan bulat

\begin{abstract}
The purpose of this study is to describe the use of the integer crossbar in improving the learning outcomes of Grade VI students of SDN 8 Labuan on the addition and subtraction of integers. This type of research refers to classroom action research (CAR) with a qualitative approach. The design of this study uses the Kemmis and Mc.Taggart model which consists of: 1) planning 2) implementing actions 3) observation and 4) reflection. Data collection techniques used were the provision of tests, interviews, observations and field notes. The instrument used was a test in the form of description. Data collection is done through three stages: (1) reducing data, (2) presenting data, and (3) drawing conclusions.The results showed that the student activities and teacher activities in learning activities in the first cycle reached the Good category and the second cycle was very good. The results of the analysis of the end of the first cycle test results obtained the percentage of the average value with the absorption of students reached $74.11 \%$ and classical learning completeness reached a percentage of $77.78 \%$ of 18 students. While the final test analysis cycle II increased according to the results of observations of student and teacher activities, the average percentage of students' absorption rate reached $80.22 \%$ with classical learning completeness reaching the target percentage of 100\% from 18 students. This has shown there is an increase in the learning outcomes of students of class VI SDN 8 Labuan on the material addition and subtraction of integers by the use of crossbar numbers
\end{abstract}

Keywords : Props crossbar, Mathematics Learning Outcomes, addition and subtraction of integers 


\section{PENDAHULUAN}

Pembelajaran matematika menuntun kita dalam berpikir kritis, logis, dan kreatif serta kemampuan bekerja sama, hal ini penting agar manusia mempunyai kemampuan memperoleh, mengelola, dan memanfaatkan informasi guna bertahan hidup dalam keadaan yang selalu berubah sesuai dengan perkembangan zaman. Salah satu cangkupan materi dalam pembelajaran matematika disekolah dasar adalah bilangan, bilangan bulat termasuk didalamnya. Bilangan bulat merupakan salah satu konsep yang terdapat dalam matematika dimana dalam pengaplikasiannya tidak jarang ditemukan dalam kegiatan kehidupan seharihari. Menurut Fathani (2009:144) bilangan bulat adalah bilangan yang seluruh anggota himpunannya terdiri atas bilangan bulat negatif, nol, dan positif. Salah satu kompetensi dasar SD dikelas VI berdasarkan Kurikulum 2013 pada pelajaran matematika adalah bilangan bulat. Materi yang diajarkan pada siswa kelas VI meliputi antara lain operasi penjumlahan dan pengurangan bilangan bulat. Menurut Muhsetyo (Setyaningsih, 2014:1) untuk mengenalkan konsep operasi bilangan bulat dapat melalui 3 tahapan yaitu tahap pengenalan konsep secara konkrit, tahap pengenalan konsep secara semi konkret dan tahap pengenalan konsep secara abstrak.

Dari pemaparan diatas dapat kita kemukakan bahwa siswa Sekolah dasar membutuhkan pengalaman fisik dan manipulasi lingkungan dalam mempelajari konsep matematika. Proses dan pengalaman yang diperoleh oleh siswa akan menjadikan konsep-konsep dalam matematika itu lebih cepat dipahami oleh siswa.

Berdasarkan pengalaman peneliti sebagai guru matematika kelas VI di SDN 8 Labuan, siswa masih kurang pemahaman materi penjumlahan dan pengurangan bilangan bulat yang melibatkan bilangan negatif dan positif sehingga berakibat hasil belajar siswa sebagian besar belum memenuhi KKM yang sudah ditentukan. Fakta ini diperoleh melalui hasil evaluasi tes kepada siswa terkait materi penjumlahan dan pengurangan bilangan bulat dan diperoleh rata-rata ketuntasan belajar yakni $38,88 \%$. ketuntasan belajar siswa masih dibawah standar ketuntasan minimum.

Penyebab kurangnya hasil belajar tersebut diantaranya dikarenakan oleh tingkat pemahaman siswa yang kurang terhadap konsep bilangan bulat, serta pelajaran matematika belum menjadi pelajaran yang di favoritkan. Hal ini didukung oleh Suwarsono (Mailili, 2012 : 039) “Matematika masih saja dianggap sebagai suatu bidang studi yang menakutkan oleh siswa dan masih banyak siswa yang belum memperoleh hasil belajar yang memuaskan. Penyebab munculnya tanggapan tersebut secara tidak langsung dipengaruhi oleh beberapa faktor, salah satunya adalah pelaksanaan pembelajaran matematika sendiri, yakni pengelolahan proses pembelajaran yang kurang efektif.

Selain itu guru juga menyadari dalam proses pembelajaran lebih banyak berceramah dan terkonsentrasi di papan tulis saat menjelaskan penjumlahan dan pengurangan bilangan bulat. Dimana guru meminta siswa mencatat contoh dan siswa mengerjakan soal sesuai dengan contoh yang sudah diberikan guru. Penjelasan guru masih terlalu abstrak bagi siswa. Guru dalam menjelaskan penjumlahan dan pengurangan bilangan bulat tanpa menggunakan media atau alat peraga yang dapat membantu mengkronkretkan konsep penjumlahan dan pengurangan bilangan bulat.

Untuk mengatasi masalah tersebut, guru perlu mengembangkan berbagai media pembelajaran atau alat peraga pembelajaran yang inovatif yang sesuai dengan kebutuhan dan karakteristik siswa, variatif, dapat meningkatkan aktifitas dan kreativitas siswa sehingga siswa terlatih dan termotivasi dalam belajar matematika yang berakibat pada meningkatnya hasil belajar matematika. Pada umumnya siswa kelas VI berusia 12 tahun keatas menurut teori piaget pada tahap ini, siswa sudah dapat berpikir secara logis tanpa kehadiranmbenda-benda konkrit, mampu melakukan abstraksi (Jaeng, 2007:32). Perkembangan dari tahap operasi konkret ke tahap ini tidak terjadi secara mendadak, ataupun berlangsung secara sempurna namun berlangsung secara perlahan-lahan olehnya pada tahun-tahun pertama ketika anak berada pada tahap ini, kemampuan anak dalam berpikir abstrak masih belum berkembang 
secara utuh sehingga dalam beberapa konteks pembelajaran anak masih membutuhkan alat peraga (benda/model konkrit).

Salah satu alat peraga yang dirasa cocok digunakan dalam mengembangkan kemampuan berpikir abstak yaitu alat peraga mistar bilangan bulat. Alat peraga pembelajaran matematika sederhana ini dapat dibuat sendiri oleh guru. Menurut Nana Sudjana (2013: 150) manfaat penggunaan alat peraga pembelajaran antara lain: pertama memberikan motivasi siswa dan guru dalam proses pembelajaran, utamanya pada siswa menimbulkan minat, kesenangan, terangsang, tertarik dan berpikir positif terhadap pengajaran matematika. Kedua Konsep abstrak matematika ditampilkan dalam bentuk yang konkrit dan olehnya itu mudah untuk dipahami dan dimengerti pada tingkatan siswa yang lebih rendah. Ketiga korelasi antara konsep matematika dengan objek yang ada di alam sekitar akan lebih mudah dipahami. Keempat konsep abstrak yang dipresentasikan dalam bentuk konkrit, yaitu dalam bentuk model matematika yang dapat dipakai sebagai objek penelitian lanjutan dan ide-ide serta gagasan baru.

Dari uraian diatas dapat kita katakan bahwa dengan penggunaan alat peraga akan membantu kelancaran proses belajar mengajar khusunya dalam pembelajaran matematika sebagai peningkatan pemahaman konsep, penguasaan teori dan definisi, sehingga siswa mempunyai penguatan ingatan bagi dalam jangka panjang sebagai subyek melalui penggunaan alat peraga pembelajaran bentuk mistar bilangan bulat

\section{METODE PENELITIAN}

Jenis Penelitian ini merupakan penelitian deskriptif dengan pendekatan kualitatif, karena peneliti ingin mendeskripsikan dan memberikan gambaran yang lebih mendalam mengenai pengunaan alat peraga mistar bilangan bulat. Subjek penelitian yaitu siswa di kelas VI SDN 8 Labuan yang terdaftar pada semester ganjil tahun ajaran 2019/2020 yang terdiri dari 18 siswa, untuk keperluan wawancara diambil 3 siswa dari siswa yang berkemampuan rendah. Peneliti memberikan instrumen berupa soalsoal uraian pada materi penjumlahan dan pengurangan bilangan bulat dan menganalisisnya. Setelah proses pembelajaran serta tes selesai dilaksanakan, peneliti melakukan wawancara kepada siswa dan mendokumentasikannya dalam transkip wawancara.

Adapun jenis data terdiri atas : (a) data kualitatif berupa hasil observasi dan wawancara, (b). data kuantitatif yaitu data hasil tes sebelum maupun sesudah tindakan. Teknik pengumpulan data digunakan : (1) pengumpulan data berupa tes sebelum dan sesudah tindakan. Adapun tujuan pemberian tes awal yaitu untuk mengetahui pengetahuan prasyarat sedang tes individu yang diberikan pada setiap akhir tindakan bertujuan untuk mengetahui hasil belajar siswa terhadap materi penjumlahan dan pengurangan bilangan bulat. (2) Wawancara dilakukan untuk memperoleh informasi tentang pemahaman siswa dalam pembelajaran materi penjumlahan dan pengurangan bilangan bulat yang diperoleh dari tes akhir tindakan. Tidak ada pedoman wawancara secara terstruktur namun bersumber dari hasil dari pekerjaan siswa serta jawaban penyelesaian yang muncul dari pertanyaan sebelumnya. Kemudian pada saat wawancara berlangsung siswa dibimbing untuk dapat memperbaiki kesalahan baik konsep maupun proses yang sudah dilakukan. (3) Observasi dilakukan menyeluruh dalam proses pembelajaran untuk mendokumentasikan aktivitas siswa dan aktivitas guru (peneliti) oleh observer (teman sejawat). (4) catatan lapangan digunakan untuk mendokumentasikan kegiatan yang tidak terdokumentasikan dalam lembar observasi.

Tahapan analisis data yang dilakukan (Moleong, 2011: 248) adalah : mereduksi data yaitu merangkum, menyeleksi, memfokuskan, dan menyederhanakan data sejak awal pengumpulan data hingga dengan penyusunan laporan. Dalam penelitian ini data hasil wawancara dan catatan lapangan direduksi sesuai dengan tujuan penelitian. (2) menyajikan data, data aktivitas siswa dalam pembelajaran dan data hasil belajar akan ditampilkan dalam bentuk table dan selanjutnya diinterpretasikan data dari hasil tabel tersebut. (3) Menyimpulkan data, data yang telah ditampilkan dan dianalisis 
selanjutnya ditarik kesimpulan berdasarkan hasil analisis tersebut. Teknik pemeriksaan keabsahan data menggunakan triangulasi, pengecekan sejawat dan kecukupan referensi(Moleong, 2011: 327).

Indikator kriteria keberhasilan dalam penelitian ini : (1) data kualitatif, data aktivitas guru dan siswa yang diperoleh dari lembar observasi dianalisis dan dinyatakan dalam bentuk presentase dan dihitung dengan rumus :

Presentase nilai rata-rata

$(\mathrm{NR})=\frac{\text { jumlah skor }}{\text { skor maksimum }} \times 100 \%$

$\begin{array}{ll}\text { Dengan kriteria keberhasilan tindakan : } \\ 90 \% \leq \mathrm{NR} \leq 100 \% & \text { sangat baik } \\ 70 \% \leq \mathrm{NR}<90 \% & \text { baik } \\ 50 \% \leq \mathrm{NR}<70 \% & \text { cukup } \\ 30 \% \leq \mathrm{NR}<50 \% & \text { kurang } \\ 0 \% \leq \mathrm{NR}<30 \% & \text { sangat kurang }\end{array}$

Ketuntasan berhasil jika nilai rata-rata minimal kategori baik untuk aktivitas siswa dan aktivitas guru. (2) Penelitian ini dilakukan dalam dua siklus. Setiap siklus dilaksanakan dengan menggunakan alat peraga mistar bilangan bulat. Di SDN 8 Labuan, siswa dikatakan tuntas belajar individu apabila hasil belajar siswa setelah mengikuti pembelajaran mencapai skor $\geq 73 \%$ sedangkan indikator keberhasilan tindakan apabila presentase ketuntasan klasikal mencapai $\geq 75 \%$.

Presentase Daya serap Individu= $\frac{\text { skor yang diperoleh siswa }}{\text { skor maksimum soal }} \times 100 \%$

Presentase ketuntasan Belajar Kalsikal = $\frac{\text { jumlah siswa tuntas }}{\text { jumlah siswa }} \times 100 \%$

Berdasarkan kesesuai kriteria yang digunakan di SDN 8 Labuan tentang kriteria ketuntasan minimal (KKM).

Prosedur penelitian merupakan tahapan-tahapan yang dilalui dalam penelitian untuk mengumpulkan data dan menjawab pertanyaan-pertanyaan dalam penelitian. Prosedur dalam penelitian ini meliputi tiga tahapan utama yaitu tahap persiapan (awal), tahap pelaksanaan dan tahap akhir. Tahap persiapan meliputi penyusunan kerangka berfikir, penyusunan instrumen penelitian yang terdiri dari tes pengetahuan penjumlahan dan pengurangan bilangan bulat, validasi instrumen oleh ahli, pembuatan alat peraga mistar bilangan bulat, penyusunan rancangan pelaksanaan pembelajaran (RPP) penggunaan alat peraga mistar bilangan bulat, penyusunan instrument observasi aktivitas siswa dan guru (peneliti). Tahap pelaksanaan terdiri dari pengunaan alat peraga mistar bilangan bulat pada materi penjumlahan dan pengurangan bilangan bulat. Memberikan tes pengetahuan mengenai penjumlahan dan pengurangan bilangan bulat serta wawancara. Dari hasil penelitian di ambil data selanjutnya diolah dan dianalisis. Tahap pelaksanaan tindakan mengacu pada model arikunto (2009:19) yang terdiri dari perencanan, pelaksanaan tindakan, observasi, dan refleksi . Tahap akhir mencakup kegiatan penyusunan laporan penelitian dan publikasi

\section{HASIL DAN PEMBAHASAN \\ A. Hasil Penelitian}

Penelitian ini dilakukan dalam dua siklus. Untuk siklus I, diawali dengan penggunaan alat peraga mistar bilangan bulat dengan materi penjumlahan dan bilangan bulat, sedangkan pada siklus II penggunaan alat peraga mistar bilangan bulat dengan materi pengurangan bilangan bulat, adapun tahapan-tahapan pelaksanaannya sebagai berikut :

1. Sebelum Guru menjelaskan secara singkat mengenai materi (penjumlahan dan pengurangan bilangan bulat), terlebih dahulu diberikan apersepsi yaitu berupa penguatan (mengingat kembali materi sebelumnya) dan mempersiapkan siswa belajar (berdoa, absensi, menyampaikan tujuan pembelajaran).

2. Membagi siswa dalam beberapa kelompok yang anggotanya $3-4$ orang pembagian kelompok berdasarkan hasil tes pada tes awal, masing-masing kelompok diberikan Lembar kerja siswa penggunaan alat peraga mistar bilangan bulat yang berisi ringkasan materi, soal penjumlahan dan pengurangan bilangan bulat.

3. Guru memulai presentasi dengan cara penggunaan mistar bilangan bulat 
terhadap materi penjumlahan dan pengurangan bilangan bulat. Dengan ketentuan sebagai berikut :

$\checkmark$ Mengawali peragan selalu dimulai dari bilangan atau skala 0 (nol).

$\checkmark$ Dari posisi awal arah ke kanan apabila bilangan yang ditambahkan bernilai positif dan arah ke kiri jika bilangan yang ditambahkan bernilai negatif kemudian melangkahlah sebanyak bilangan yang akan ditambahkan atau dikurangkan.

$\checkmark$ Saat berada pada posisi kedua. Menentukan arah menghadap dalam melangkah ditentukan pada bilangan kedua yang bilangan penambah atau pengurang.

$\checkmark$ Menentukan langkah maju atau mundur berdasarkan tanda operasi. Melangkah maju apabilah tanda operasinya(+) dan mundur apabila (-).

$\checkmark$ Menentukan jumlah langkah maju atau mundur berdasarkan bilangan kedua atau bilangan penambah atau pengurang.

4. Guru mengamati aktivitas siswa pada masing-masing kelompok saat pengerjaan lembar kerja siswa, apa bila waktu memungkinkan guru memberikan kesempatan bagi siswa mengulang kembali peragaan penggunaan alat peraga mistar bilangan bulat. Menurut Dimyani dan Mudjiono (Riyanto, 2008: 73) “ perlunya pengulangan adalah untuk melatih daya yang ada pada manusia yang terdiri atas daya pengamat, menanggap,meningat, menghayal, merasakan, berpikir dan sebagainnya. Dengan adanya pengulangan maka daya tersebut akan berkembang"

5. Tahap akhir, siswa dipersilahkan untuk mengumpulkan lembar kerja masingmasing. Selanjutnya dilakukan diskusi dan membuat kesimpulan materi penjumlahan dan pengurangan bilangan bulat. Penyajian dan penggunaan alat peraga yang baik akan menarik perhatian siswa sehingga menimbulkan suasana menyenangkan.

Setelah menerapkan penggunaan alat peraga mistar bilangan bulat pada materi penjumlahan dan pengurangan bilangan bulat di SDN 8 Labuan, Adapun hasil yang diperoleh setelah melaksanakan pembelajaran tersebut sebagai berikut :

1. Pada siklus I, berdasarkan perolehan skor tes akhir, ternyata jumlah siswa yang tuntas atau memperoleh skor $\geq 73$ adalah 14 orang dari 18 siswa yang mengikuti ujian, dengan presentase ketuntasan klasikal sebesar 77,78 \% dan presentase daya serap klasiskal sebesar 74,11\%. Berdasarkan analisis lembar observasi kegiatan siswa maka diperoleh presentase nilai rata-rata (NR) sebesar 86,53\% dengan kategori baik. Sedangkan untuk analisis kegiatan guru diperoleh presentase nilai rata-rata (NR) sebesar 88,23\% dengan kategori baik.

2. Pada Siklus II , berdasarkan perolehan skor tes akhir, ternyata jumlah seluruh siswa yang tuntas atau memperoleh skor $\geq 73$,dengan presentase ketuntasan klasikal sebesar $100 \%$ dan presentase daya serap klasiskal sebesar $80,22 \%$. Berdasarkan analisis lembar observasi kegiatan siswa maka diperoleh presentase nilai rata-rata (NR) sebesar 94,25 \% dengan kategori sangat baik. Sedangkan untuk analisis kegiatan guru diperoleh presentase nilai rata-rata (NR) sebesar 95,58\% dengan kategori sangat baik

\section{B. Pembahasan}

Berdasarkan hasil penelitian, diperoleh data dari analisis yaitu untuk tes awal, diperoleh ketuntasan belajar klasikal sebesar $38,88 \%$ dan jumlah siswa yang memperoleh daya serap individu lebih besar atau sama dengan 73 sebanyak 7 orang dari 18 siswa. Hal ini menunjukkan bahwa pemahaman siswa tentang penjumlahan dan pengurangan bilangan bulat (materi prasyarat) masih rendah. Untuk tes akhir tindakan siklus I diperoleh presentase ketuntasan belajar klsikal sebesar $77,78 \%$ dan jumlah siswa yang memperoleh daya serap individu lebih besar atau sama dengan 73\% sebanyak 14 orang dari 18 siswa. Hasil tes akhir siklus I menunjukkan adanya peningkatan bila dibandingkan dengan hasil tes awal, dengan demikian data yang diperoleh pada siklus I menunjukkan bahwa indikator keberhasilan tindakan telah dicapai. Ini berarti kemampuan siswa dalam menyelesaikan soal yang berkaitan dengan penjumlahan 
bilangan bulat sudah baik. Dari pengamatan yang dilakukan oleh observer, keaktifan siswa yang mengikuti pembelajaran sudah baik, hal ini ditunjukkan dengan antusias siswa dalam mengikuti pembelajaran dikelas.

Kemudian pada siklus II, dari hasil analisis tes akhir tindakan diperoleh ketuntasan belajar klasikal sebesar $100 \%$ dan semua siswa memperoleh daya serap individu lebih besar atau sama dengan 73 . Hal ini menunjukkan bahwa kemampuan siswa dalam menyelesaikan soal yang berkaitan dengan pengurangan bilangan bulat lebih baik dan telah meningkat.

Peningkatan hasil belajar ini merupakan dampak postif dari pengunaan alat peraga mistar bilangan bulat. Penggunaan alat peraga membantu pengajar dalam menyampaiakan materi sehingga lebih menarik para siswa bisa memahami materi yang disampaikan dengan baik serta dapat meningkatkan prestasi belajar belajar siswa. Menurut Mujiono (Sundayana, 2014:25) ada empat komponen penting yang berpengaruh dalam keberhasilan belajar siswa yang perlu diperhatikan dalam proses belajar mengajar yakni bahan suasana belajar, bahan ajar, media dan sumber belajar serta guru sebagai subyek pembelajaran. Hal tersebut menjadi penting dalam proses belajar mengajar sebab kurangnya salah satu atau lebih komponen tersebut akan menghambat tercapaiannya tujuan belajar yang optimal. Media dalam hal ini penggunaan alat peraga dalam pembelajaran merupakan salah satu komponen dalam kegiatan belajar mengajar dalam upaya peningkatan tujuan pembelajaran yang lebih baik, olehnya guru sebagai subyek pembelajaran harus dapat memilih media (alat peraga) dan sumber belajar yang tepat, melakukan inovasi dalam pembelajaran, sehingga bahan pelajaran yang disampaikan dapat diterima siswa dengan baik.

\section{KESIMPULAN}

Berdasarkan tahapan penelitian yang telah dilaksanakan dapat diberikan kesimpulan dan jawaban terhadap pertanyaan permasalahan penelitian antara lain :

1. Pembelajaran dengan menggunakan alat peraga mistar bilangan bulat pada materi penjumlahan dan pengurangan bilangan bulat dapat meningkatkan hasil belajar siswa kelas VI SDN 8 Labuan.

2. Tahap-tahap penting yang dilakukan dalam menggunakan alat peraga mistar bilangan bulat sehingga dapat meningkatkan hasil belajar siswa, antara lain :

a. Tahap awal, memberikan motivasi, penguatan materi, memberi contoh (apersepsi)

b. Tahap inti (penyampaian materi)

c. Tahap inti (Presentasi, penggunaan alat peraga mistar bilangan bulat)

d. Tahap inti ( diskusi)

e. Tahap Akhir (membimbing siswa untuk memberikan kesimpulan)

3. Hasil belajar yang diperoleh siswa pada materi penjumlahan dan pengurangan bilangan bulat menunjukkan peningkatan yang signifikan. Hal ini ditunjukkan dari presentase ketuntasan belajar klasikal yang diperoleh pada sisklus I adalah $77,78 \%$ dan siklus II adalah $100 \%$.

4. Penggunaan alat peraga mistar bilangan bulat merupakan salah satu alternatif dalam pembelajaran agar tercipta suasana belajar yang menyenangkan sehingga proses belajar dapat terjadi secara alami dan tidak monoton. Dengan penggunaan alat peraga ini membantu siswa dalam belajar matematika berpikir konkret ke abstrak, meningkatkan sikap positif siswa dalam belajar matematika sehingga siswa lebih termotivasi dan antusias dalam belajar matematika khususnya penjumlahan dan penguranga bilangan bulat

\section{DAFTAR PUSTAKA}

Arikunto, S.(2009). Penelitian tindakan kelas. Jakarta : PT.Bumi Aksara.

Fathani, Abdul Halim. 2009. Matematika Hakikat dan Logika. Yogyakarta: Arruzz Media.

Jaeng,M. (2007). Belajar dan Pembelajaran Matematika. Palu : FKIP Universitas Tadulako.

Mailili, Wahyuni H. (2012). Efektivitas Penerapan Media Pembelajaran 


\section{Penggunaan Alat Peraga}

berbentuk Kartu Domino pada penjumlahan dan pengurangan bilangan bulat. Palu : FMIPA Untad.Media Eksakta Jurnal Matematika dan Sains vol. 8. No. 1. Hal. 038-043.

Moleong, L. (2011). Metodologi Penelitian Kualitatif. Bandung : Remaja Rosdakarya.

Riyanto, Yatim (2008). Paradigma baru pembelajaran. Jakarta : Pustaka Kencana.

Setyaningsih, Andri Nina. 2014. Penggunaan media mistar bilangan bulat untuk meningkatkan hasil belajar penjumlahan bilangan bulat pada sekolah dasar. Surabaya:
JPGSD.Volume 02 Nomor 02. Hal. 114.

Sudjana, Nana. 2013. Dasar-Dasar Proses Belajar Mengajar. Bandung: Sinar Baru Algensindo.

Sundayana, H. Rostina. 2014. Media dan alat peraga dalam pembelajaran matematika.Bandung: Alfabeta 